https://doi.org/10.15407/scine17.03.087

TAGAEV, I. A.' (https://orcid.org/0000-0002-4268-7336), MURATOVA, M. N.' (https://orcid.org/0000-0001-6204-9182), ANDRIYKO, L. S. ${ }^{2}$ (https://orcid.org/0000-0001-5558-5374), and BOYKHONOVA, M. Yu. ${ }^{3}$ (https://orcid.org/0000-0001-8487-9443)

'Navoi State Mining Institute, 170, Galaba Ave., Navoi, 210100, Uzbekistan, +9980436223 4966, info@ndki.uz

${ }^{2}$ Chuiko Institute of Surface Chemistry, the NAS of Ukraine, 17, General Naumov St., 03164, Kyiv, Ukraine,

+ 380444243567 , info@isc.gov.ua

${ }^{3}$ Navoi branch of the Academy of Sciences of Uzbekistan, 170, Galaba Ave., Navoi, 210100, Uzbekistan, +998 7922342 15, navoiy@academy.uz

\title{
CHARACTERISTICS OF NEW PROMISING BENTONITE COAL SORBENTS MODIFIED BY DIFFERENT COMPOUNDS
}

Introduction. Bentonite clays are traditional inexpensive and effective adsorbents that have a high potential for removing heavy metals from wastewater due to their abundance, chemical and mechanical stability, high exchange ability, and unique structural properties.

Problem Statement. To obtain activated carbon, high-temperature muffle furnaces are used with the consumption of a large amount of electricity, which is economically unprofitable. In addition, the resulting sorbents must be in the form of granules or tablets, have high strength and the ability to be repeatedly used in technological processes.

Purpose. Development of a method for the production of low-cost granular sorbents based on bentonite as a mineral component, activated carbon, as well as natural production waste (sunflower husk, straw, sawdust, etc. as modifiers), which can be removed from the activation process to increase porosity of these materials.

Materials and Methods. Angren brown coal; bentonite of the Navbakhor deposit was used as a sorbent and a basic substance for the granules formation; modifiers were sodium chloride, potassium, chopped straw, sawdust. Methods of thermal decarbonization and activation of the obtained granules under the optimal conditions $\left(950^{\circ} \mathrm{C}\right.$, $45 \mathrm{~min}$ ) were applied; the bulk density, the specific surface area, pore types and their total volume was determined by optical microscopy and nitrogen adsorption methods.

Results. Inexpensive hybrid bentonite-carbon sorbents in the form of high-strength granules were synthesized. The optimal ratio of the main components is Bentonite:Coal $=1: 2$, size $(2.5 \mathrm{~mm})$ and strength of granules (83$99 \%$ ), total pore volume $0.863-1.01 \mathrm{~cm}^{3} / \mathrm{g}$, confirmed the presence of macro-, meso- and micropores. The most promising sample has a specific surface area (Langmuir) $184 \mathrm{~m}^{2} / \mathrm{g}$.

Conclusions. The method for obtaining new effective granular carbon sorbents of low cost, having high sorption capacity relative to organic and inorganic pollutants for purification of industrial process waters has been proposed.

Keyw ords: coal, bentonite clays, activation, carbonization, microscopic structure, and bentonite-coal sorbents.

Citation: Tagaev, I. A., Muratova, M. N., Andriyko, L. S., and Boykhonova, M. Yu. Characteristics of New Promising Bentonite Coal Sorbents Modified by Different Compounds. Sci. innov. 2021. V. 17, no. 3. P. 87-95. https://doi.org/10.15407/scine17.03.087 
Activated carbon, zeolites, clays, graphene oxides, carbon nanotubes, mesoporous silica, waste biomass and tar have been acknowledged as very effective adsorbents [1]. Bentonite clays (montmorillonite), kaolinite, biotite, vermiculite, attapulgite (palygorskite), glauconite are traditional inexpensive and effective adsorbents that have a high potential for removing heavy metals from wastewater due to their abundance, chemical and mechanical stability, high exchange ability and unique structural properties. The prospect of their use is associated, firstly, with the availability and low cost of raw materials, and secondly, with sufficiently high service characteristics: water purification, prevent mechanical stress, can take any form without the use of mechanisms, retain not only toxins, but also moisture, liquefy at rest, become denser in use [2-4].

As an alternative to known adsorbents, granular clay-carbon composites are considered as highly effective materials for removing pollutants [5-8]. Due to their branched porous structure and additional complex adsorption mechanisms, the water treatment process takes place much faster with fairly easy regeneration of the spent adsorbent [9]. Clay-carbon composites consist mainly of bentonite or kaolin clays and activated carbon $[10,11]$. The use of activated carbon significantly reduces the cost of such composites, which will allow them to be used effectively in proceedings instead of expensive synthetic sorbents [12].

In this light, the relevant objective is to increase the sorption properties of such clay-carbon composites by applying various modifications, using affordable, inexpensive reagents and simple technological operations [13-16]. In this case, a directed change in the structure of the resulting sorbent occurs, which leads to an increase in the specific surface of the material, its porosity, the number of exchange centers, etc., and as a result, to an increase in its sorption properties. Inorganic and organic natural materials or production wastes can be used as modifying agents - alfalfa seeds, clover, rice husk, sawdust, etc. [13], as well as ther- mal and electromagnetic processing. Modifying agents during thermal decarbonization and activation should have the ability to be removed from the process and thus increase the sorbent porosity and improve its sorption properties.

Another limiting factor in the widespread usage of natural sorbents for the drinking water treatment and industrial effluents is the lack of effective granulation technologies, since clay minerals are exposed to peptization in aqueous media [16-19].

Thus, the purpose of this research is the development of a production method for inexpensive granular sorbents based on bentonite as a mineral component, activated carbon and natural raw materials as a modifier (potassium salts, sodium, fine straw and sawdust), which at high temperatures and in the absence of oxygen can completely burn out and to be removed with exhaust gases from the muffle furnace. Thereat, numerous pores of various sizes appear at the burnout site of these agents, which significantly increases the sorption ability of the obtained granular bentonitecoal sorbents. The performed research work showed that for repeated use, sorbents together with high strength should be in the form of granules or tablets for subsequent extraction from the process, regeneration and further usage.

\section{Results and Discussion}

The method of obtaining hybrid bentonite-coal sorbents is presented in detail in a previous work [20]. The optimal option for the manufacture of bentonite-coal sorbents was selected in the ratio bentonite: $c o a l=1: 2$. Bentonite was used not only as a sorbent, but also as a binder to shape the granules. The optimal thermal activation of the granules was annealing at a temperature of $950{ }^{\circ} \mathrm{C}$ for 45 minutes. Initial parameters for decarbonization and activation were used based on patent sources for coal activation [20-21].

Table 1 shows the results of a decrease in the mass of initial materials and samples of sorbents upon the decarbonization and activation processes. A wide range of samples is presented, including using soot from the methane pyrolysis pro- 
cess provided by JSC Navoiyazot. Sich kind of soot is considered a production waste.

The highest degree of mass loss of the organic component during decarbonization and activation can be noted in the initial version with coal, which amounted to $36.9 \%$, with soot $-41.2 \%$. For selected variant $\mathrm{B}: \mathrm{C}=1: 2$ the degree of decarbonization was $21.5 \%$. BC- $12 / 0-10$ variant is modified with sawdust in the amount of $10 \mathrm{~g}$ per $100 \mathrm{~g}$ of bentonite, $200 \mathrm{~g}$ of coal and $500 \mathrm{ml}$ of water. Burning of sawdust during decarbonization led to an increase in the degree of decarbonization to $34.6 \%$. With the possible advantages of this variant in terms of sorption and ion-exchange capacities, as well as strength, this sample will not give an economic effect due to the large consumption of initial material. Variants with soot have showed a lower decarbonization degree from 6.2 to $8.3 \%$. During studying the sorption capacity, the granules isolated soot that stained water in black and therefore variants with soot were excluded from experiments.

Coal, as a flowing substance, is characterized by bulk density, which is a quantitative expression of the ratio of the coal mass to the volume filled freely or uncompressed. Bulk density depends

Table 1. Decrease in the Mass of Sorbents during Decarbonization and Activation in a Muffle Furnace $\left(950{ }^{\circ} \mathrm{C}\right.$, time - $\left.45 \mathrm{~min}\right)$

\begin{tabular}{|c|c|c|c|}
\hline Mass ratio & $\begin{array}{c}\text { The initial } \\
\text { mass, } g\end{array}$ & $\begin{array}{c}\text { After } \\
\text { activation, } g\end{array}$ & $\begin{array}{c}\text { The degree } \\
\text { of decrease } \\
\text { in the mass, } \%\end{array}$ \\
\hline \multicolumn{4}{|c|}{ Bentonite : Coal } \\
Bentonite & 5 & 4 & 20.0 \\
Coal & 10 & 6.31 & 36.9 \\
$1: 1$ & 165.37 & 127.53 & 22.8 \\
$1: 2$ & 136.71 & 107.33 & 21.5 \\
BC-12/o-10 & 110.52 & 72.52 & 34.6 \\
& Bentonite : Soot & \\
Bentonite & 5 & 4 & 20.0 \\
Soot & 8 & 4.7 & 41.2 \\
$1: 1$ & 630.01 & 468.48 & 25.6 \\
$1: 2$ & 577.05 & 528.91 & 8.3 \\
$2: 1$ & 563.25 & 528.41 & 6.2 \\
\hline
\end{tabular}
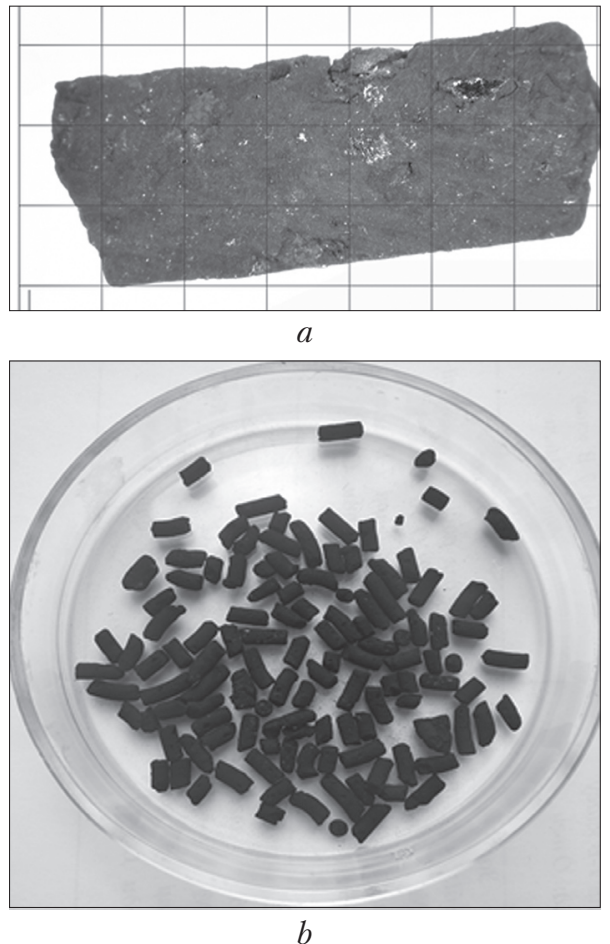

Fig. 1. The image of the granules of bentonite-coal adsorbents BC-12/SN-5: $a$ - increase in $\times 250$ times, $b$ - actual size

on ash content, moisture content, particle size distribution, particle shape and placement. The determination of bulk density was carried out in accordance with the GOST P 54246-2010 methodology [23]. Bulk density $X, \mathrm{~g} / \mathrm{cm}^{3}$, is calculated by the formula:

$$
X=\frac{\left(M_{1}-M_{2}\right)}{V},
$$

where $M_{1}$ is weight of cylinder with adsorbent, g; $M_{2}$ is empty cylinder weight, $g$; $V$ is adsorbent volume, $\mathrm{cm}^{3}\left(10 \mathrm{~cm}^{3}\right)$. According to formula (1), the bulk density of the obtained samples of bentonite-carbon sorbents was determined, which varied in the range from 0.38 to $0.54 \mathrm{~g} / \mathrm{cm}^{3}$ (Table 2).

When studying the size of the granules in variant 1, the diameter of the granules was $4.5 \mathrm{~mm}$, and in variant 2 , granules with a diameter of up to $2.5 \mathrm{~mm}$ were obtained. With a decrease in the granules size, the total pore volume increases. This leads to an increase in the specific surface area. If 


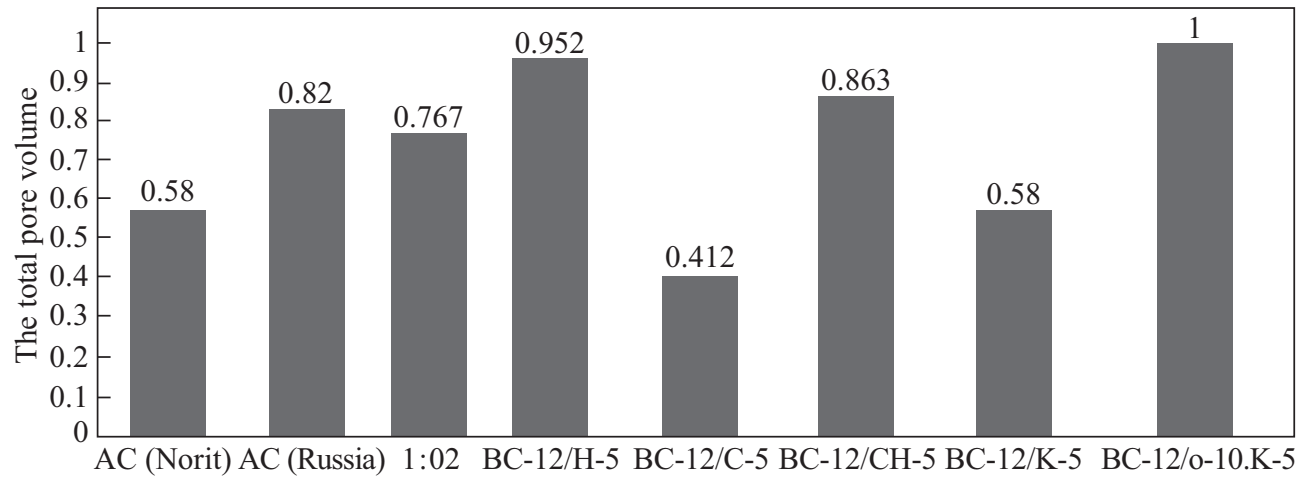

Fig. 2. The total pore volume $\left(\mathrm{cm}^{3} / \mathrm{g}\right)$ of bentonite-coal sorbents in comparison with the industrial sorbents activated carbon Norit (Holland) and activated carbon (Russia)

in variant 1 with a granule diameter of $4.5 \mathrm{~mm}$, the total pore volume is $0.478 \mathrm{~cm}^{3} / \mathrm{g}$, then a decrease in granule size to $2.5 \mathrm{~mm}$ led to an increase in pore volume to $0.767 \mathrm{~cm}^{3} / \mathrm{g}$. Thus, all subsequent studies were carried out to obtain samples having a granule diameter of $2.5 \mathrm{~mm}$ (Table 2).

The image of the obtained granules of bentonite-coal adsorbents was taken by Digital Portable Microscope Dino-Lite Special lighting-UV AM4113FVT (Taiwan). The image of the obtained granules of bentonite-coal adsorbents is shown in Fig. 1.

The modification of bentonite-coal sorbents was carried out as follows: per $100 \mathrm{~g}$ of bentonite, $200 \mathrm{~g}$ of coal and $500 \mathrm{ml}$ of water such modifying reagents were added $-\mathrm{NaCl} 5 \mathrm{~g}(\mathrm{BC}-12 / \mathrm{N}-5)$, finely chopped straw $5 \mathrm{~g}$ (BC-12/S-5), a mixture of $\mathrm{NaCl} 5 \mathrm{~g}$ and straw $5 \mathrm{~g}(\mathrm{BC}-12 / \mathrm{SN}-5), \mathrm{KCl} 5 \mathrm{~g}$ (BC-12/K-5) as well as a mixture $\mathrm{KCl} 5 \mathrm{~g}$ and sawdust $10 \mathrm{~g}$ (BC-12/o-10,K-5). The strength of the granules was determined on a vibrating screen
(80 vibrations per second) for 7 minutes. The total pore volume was determined in accordance with GOST 17219-71 [24].

This method allows us to approximately determine the total pore volume of activated carbons with a diameter of fractions from 0.2 to $5 \mathrm{~mm}$. The calculation of the total porosity $V_{\Sigma}\left(\mathrm{cm}^{3} / \mathrm{g}\right)$ was carried out according to the following formula:

$$
\mathrm{V}_{\Sigma}=\frac{\left(m_{w . c .}-m_{d . c .}\right)}{m_{d . c .} r_{w}},
$$

where $m_{w \cdot c}$ is wet coal weight, $g ; m_{d . c}$ is dry coal weight, $g ; \rho_{w}$ is water density, $\mathrm{g} / \mathrm{cm}^{3}$ (taken equal to $1 \mathrm{~g} / \mathrm{cm}^{3}$ at room temperature not exceeding $35^{\circ} \mathrm{C}$ ).

Table 2 demonstrates the texture characteristics of bentonite-coal sorbents modified by various reagents. We can see that the granules strength of these samples varies within $83-99 \%$. The most promising three samples with a large total pore volume: BC- $12 / \mathrm{N}-5-0.952 \mathrm{~cm}^{3} / \mathrm{g}, \mathrm{BC}-12 / \mathrm{SN}-5-$ $0.863 \mathrm{~cm}^{3} / \mathrm{g}$ and BC-12/o-10.K-5 - $1.01 \mathrm{~cm}^{3} / \mathrm{g}$.

Table 2. Texture Characteristics of Bentonite-Coal Sorbents Modified by Various Reagents $\left(t=950{ }^{\circ} \mathbf{C}\right)$

\begin{tabular}{|c|c|c|c|c|c|c|}
\hline Diameter, mm & Sample names B : C & Strength, \% & Bulk density, $\mathrm{g} / \mathrm{cm}^{3}$ & $m_{d . c} \mathrm{~g}$ & $m_{w . c} \mathrm{~g}$ & $\mathrm{~V}_{\Sigma}, \mathrm{cm}^{3} / \mathrm{g}$ \\
\hline 4.5 & $1: 2$ & 93.5 & 0.42 & 127.53 & 188.60 & 0.478 \\
2.5 & $1: 2$ & 98.5 & 0.54 & 44.61 & 78.83 & 0.767 \\
2.5 & BC-12/N-5 & 83.0 & 0.40 & 102.12 & 199.44 & 0.952 \\
2.5 & BC-12/S-5 & 98.9 & 0.42 & 168.88 & 238.57 & 0.412 \\
2.5 & BC-12/SN-5 & 96.5 & 0.38 & 121.87 & 227.11 & 0.863 \\
2.5 & BC-12/K-5 & 93.0 & 0.46 & 133.97 & 211.71 & 0.580 \\
2.5 & BC-12/o-10.K-5 & 96.0 & 0.41 & 72.5 & 110.88 & 1.01 \\
\hline
\end{tabular}



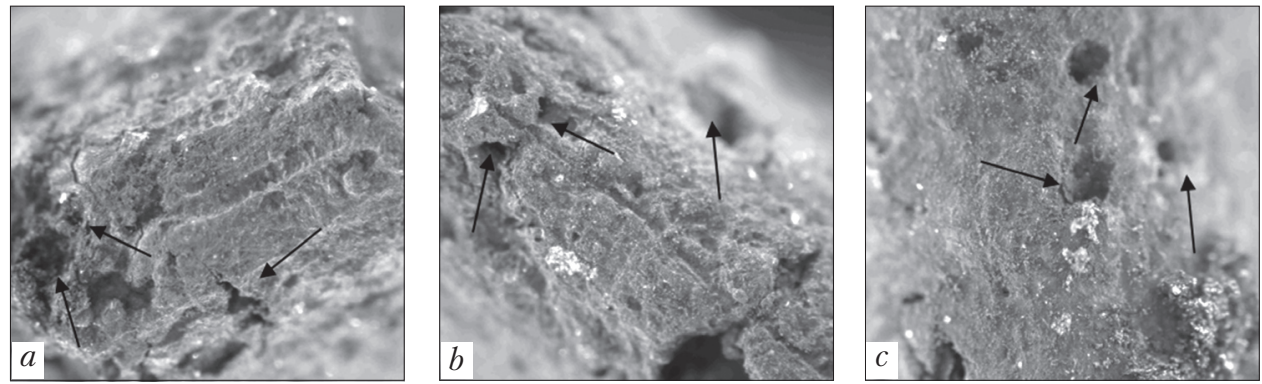

Fig. 3. Microphotographs of modified bentonite-carbon sorbents in reflected light: $a-\mathrm{BC}-12 /$ $\mathrm{N}-5 ; b-\mathrm{BC}-12 / \mathrm{SN}-5 ; c-\mathrm{BC}-12 / \mathrm{o}-10, \mathrm{~K}-5$

In comparison with the reference samples of activated carbons of Dutch and Russian productions, the obtained bentonite-carbon adsorbents (with the exception of sample BC-12/S-5) have a larger total pore volume, which indicates the presence of a developed structure of macro-, mesoand micropores for these adsorbents (Fig. 2) [25]. Therefore, it will allow using them effectively for solving a wide range of tasks in industry, protecting the environment and human life.

Microphotographs of samples of bentonitecoal sorbents modified with $\mathrm{NaCl}, \mathrm{KCl}$, straw and sawdust were performed on a Primo Star optical microscope (Zeiss, Germany) in transmitted light at $\times 1000$ magnification (Fig. 3).

The macropores indicated by arrows are clearly visible in the figure. The presence of mesopores can be noted by the degree of looseness of the material. Activation at $950{ }^{\circ} \mathrm{C}$ for 45 minutes was optimal, in which new, promising samples of sorbents were obtained, characterized by the presence of different types of pores, which are divided into macro-, meso- and micropores. All types of cations and anions are retained in these sorbent pores. Large molecules are able to be retained by macropores, small ones by micropores. [26-28].

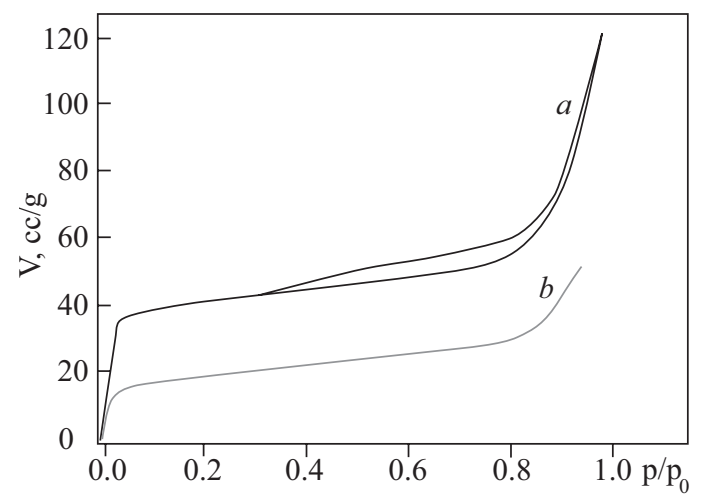

Fig. 4. Nitrogen adsorption-desorption isotherms by porous adsorbents based on bentonite and coal, taken in the ratio: $a-\mathrm{BC}-12 / \mathrm{SN}-5 ; b-\mathrm{BC}-12 / \mathrm{o}-10, \mathrm{~K}-5$

The pore size and area was determined by the method of low temperature nitrogen adsorption for samples 1 . BC- $12 / \mathrm{N}-5$, 2. BC- $12 / \mathrm{SN}-5$, 3. BC-12/o-10,K-5, with the use of the volumetric method and Kelvin-1042 (Costech Microanalytical) at the boiling point of liquid nitrogen (Fig. 4-5, Table 3). In this case, the sorbents were previously degassed in a helium stream at a temperature of $110-120^{\circ} \mathrm{C}$. The volume of adsorbed gas was determined at the time of quasiequilibrium in the gas stream, which was controlled by a thermal conductivity detector (measurement accuracy $\pm 3 \%$ ).

Table 3. Structural Characteristics of Bentonite-Coal Absorbents Calculated from Nitrogen Adsorption Isotherms

\begin{tabular}{|c|c|c|c|c|c|c|}
\hline Ratio & $S_{\text {specific }}, \mathrm{BET} \mathrm{m}^{2} / \mathrm{g}$ & $\begin{array}{c}S_{\text {specific }} \text { Langmuir, } \\
\mathrm{m}^{2} / \mathrm{g}\end{array}$ & $V_{\text {micpo }}, \mathrm{mm}^{3} / \mathrm{g}$ & $\begin{array}{c}\text { Micropore } \\
\text { area, } \mathrm{m}^{2} / \mathrm{g}\end{array}$ & $\begin{array}{c}\text { Non microporous } \\
\text { surface area, } \mathrm{m}^{2} / \mathrm{g}\end{array}$ & $\begin{array}{c}\text { Average diameter, } \\
D, \mathrm{~nm}\end{array}$ \\
\hline BC-12/N-5 & 35.142 & 45.070 & 17.93 & 50.875 & -5.805 & - \\
$\mathrm{BC}-12 / \mathrm{SN}-5$ & 128.85 & 184.02 & 38.01 & 107.871 & 20.980 & 60.21 \\
BC-12/o-10.K-5 & 62.90 & 86.53 & 10.90 & 30.940 & 31.965 \\
\hline
\end{tabular}



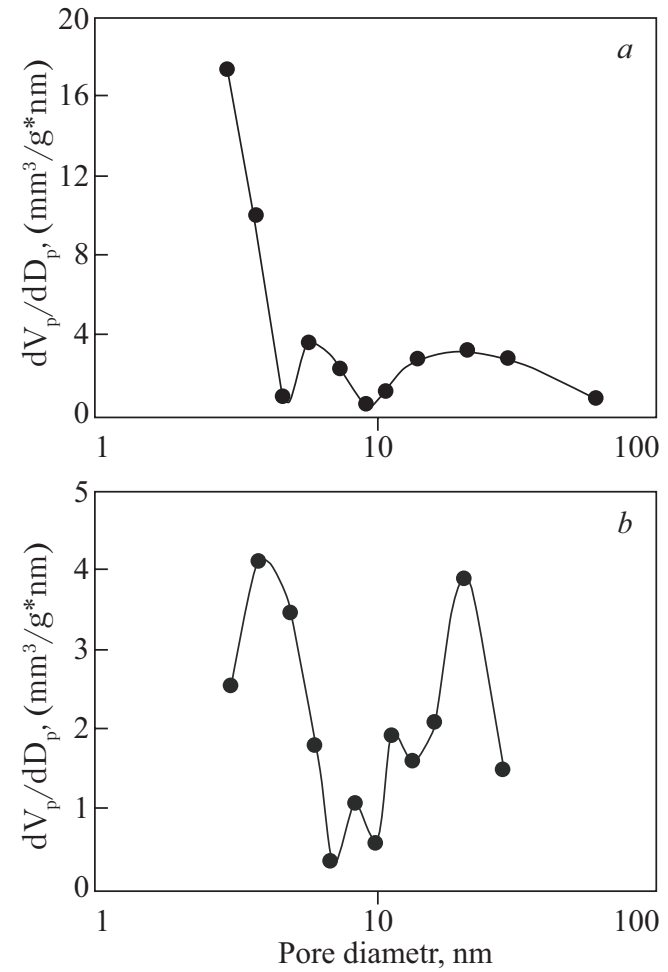

Fig. 5. Pore size distributions by porous adsorbents based on bentonite and coal, taken in the ratio: $a-\mathrm{BC}-12 / \mathrm{SN}-5 ; b-$ BC-12/o-10, K-5

The convenience of this type of equipments is that they operate in automatic mode and allow the study of adsorbents with low specific surface area and have software - both for research and for calculations with the use of various models of adsorption processes [27, 29-33].

The specific surface area $S_{\text {spesific }}$ was determined with the use of the adsorption value when filling the monomolecular layer $a_{m}$. The monolayer capacity was determined by the BET method [2931]. The specific surface area is calculated by the equation:

$$
S=a_{m} N \omega_{0},
$$

where $N$ is Avogadro number; $\omega_{0}$ is area occupied by an adsorbed molecule in a dense monomolecular layer.

The $a_{m}$ value was determined from the $B E T$ equation, a graphical solution of this equation allows us to find am and the constant $C$. The equation can be applied in the field of relative pressure
$P / P_{s}=0.03-0.35$. Calculations can also be carried out by processing experimental data, for example, by the least squares method, and implemented in the software product of the aforementioned supplier company. The results of just such processing were used in this work.

The shape of the adsorption isotherms is a reflection of the porous structure of an adsorbent. Moreover, different sections of the adsorption isotherm, depending on the pore size and their ratio in the structure of the porous body, have a different effect on its shape. For the studied samples of bentonite-coal adsorbents, the adsorption isotherm in the low-pressure region rises more abruptly. This type of adsorption-desorption nitrogen isotherm indicates that macropores are present in the samples. The type of hysteresis loop (curve a) makes it possible to assert that the pores are predominantly cylindrical shape (Fig. 4) [27].

Curves of pore size distribution calculated from nitrogen adsorption-desorption isotherms demonstrate the presence of different types of pores in the samples. According to the pore classification adopted by the International Union of Theoretical and Applied Chemistry (IUPAC) for sample BC-12/ $\mathrm{SN}-5$, three maxima are characteristic that relate to macro- $(\mathrm{R}=40-50 \mathrm{~nm})$, meso- $(\mathrm{R}=4-40 \mathrm{~nm})$ and micropores $(\mathrm{R}=1-4 \mathrm{~nm})$ (Fig. 5, curve $a)$. For the sample BC-12/o-10, K-5 is characterized by the presence meso- $(\mathrm{R}=5-20 \mathrm{~nm})$ and micropores $(\mathrm{R}=2-4 \mathrm{~nm})$ (Fig. 5, curve $b)$. The macropores diameter corresponds to the pressure near $p / p_{0}=1[27,34]$, usually such pores weakly participate in the adsorption process and, for several reasons, capillary condensation practically does not occur in them, therefore, they play the role of transport pores in the structure of a solid body.

Table 3 shows the structural adsorption characteristics of the selected bentonite-carbon sorbents calculated from nitrogen adsorption isotherms. Tabular material allows us to select the most promising sample BC-12 / SN-5 with a specific surface area $S_{\text {specific }},(B E T)=128.85 \mathrm{~m}^{2 / \mathrm{g}}\left(S_{\text {specific }}\right.$, $($ Langmuir $\left.)=184.02 \mathrm{~m}^{2} \mathrm{~g}\right)$ micropore area equal to $107.87 \mathrm{~m}^{2} \mathrm{~g}$. These values are within the mi- 
nimum range of $100-1500 \mathrm{~m}^{2} / \mathrm{g}$ needed for industrial application and removal of small molecules. [35].

\section{Conclusions}

The experimental studies on the production of hybrid granular bentonite-carbon sorbents have shown the promise of this research area. The optimal ratio of components is bentonite: coal $=1: 2$. Samples with bentonite and soot polluted the cleaned medium by the release of finely dispersed organic carbon and therefore were excluded from further studies. When studying the granule size, it was found that a decrease in the diameter of the granules to $2.5 \mathrm{~mm}$ leads to an increase in pore volume from 0.478 to $0.767 \mathrm{~cm}^{3} / \mathrm{g}$. Thus, their optimal sizes were determined.
The selection of such starting materials as bentonite and coal that are natural sorbents with a lower sorption capacity has made it possible to obtain a hybrid version of bentonite-carbon sorbent with a higher sorption capacity. The use of available natural materials from production waste as modifying agents (potassium chloride, sodium chloride, chopped straw and sawdust), capable of being removed from the activation process, leads to an increase in the degree of porosity of the obtained samples.

Thus, there is a high potential for using such inexpensive bentonite-coal sorbents with a developed porous structure in the form of highly durable granules after additional studies to purify industrial process waters from heavy metal ions and other pollutants. Further research is ongoing to identify the best among all these potential adsorbents.

\section{REFERENSES:}

1. Singh, N. B., Nagpal, G., Agrawal, S. (2018). Water purification by using adsorbents. A Review. Environ. Technol. Innov., 11, 187-240. https://doi.org/10.1016/j.eti.2018.05.006

2. Wang, J., Chen, C. (2009). Biosorbents for heavy metals removal and their future. Biotechnology advances, 27(2), 195226. https://doi.org/10.1016/j.biotechadv.2008.11.002

3. Uslu, H., Datta, D., Azizian, S. (2016). Separation of chromium (VI) from its liquid solution using new montmorillonite supported with amine based solvent. Journal of Molecular Liquids, 215, 449-453 https://doi.org/10.1016/j.molliq.2016.01.023

4. Qiu, G., Xie, Q., Liu, H., Chen, T., Xie, J., Li, H. (2015). Removal of Cu (II) from aqueous solutions using dolomite-palygorskite clay: performance and mechanisms, Applied clay science, 118, 107-115. https://doi.org 10.1016/j.clay.2015.09.008

5. Foroutan, R., Zareipour, R., Mohammadi, R. (2018). Fast adsorption of chromium (VI) ions from synthetic sewage using bentonite and bentonite/bio-coal composite. A comparative study. Materials Research Express, 6(2), 025508. https://doi. org 10.1088/2053-1591/aaebb9

6. Hiew, B. Y. Z., Lee, L. Y., Lai, K. C., Gan, S., Thangalazhy-Gopakumar, S., Pan, G.-T., Yang, T. C.-K. (2019). Adsorptive decontamination of diclofenac by three-dimensional graphene-based adsorbent: Response surface methodology, adsorption equilibrium, kinetic and thermodynamic studies. Environmental Research, 168, 241-253. https://doi.org/10.1016/j. envres.2018.09.030

7. Anastopoulos, I., Mittal, A., Usman, M., Mittal, Y., Yu, G., N ez-Delgadofez, A., Kornaros, M. (2018). A review on halloysite-based adsorbents to remove pollutants in water and wastewater. Journal of Molecular Liquids, 269, 855-868. https://doi.org/10.1016/j.molliq.2018.08.104

8. Okiel, Kh., El-Sayed, M., El-Kadyc Y. M. (2011). Treatment of oil-water emulsions by adsorption onto activated carbon, bentonite and deposited carbon. Egyptian Journal of Petroleum, 20(2), 9-15. https://doi.org/10.1016/j.ejpe.2011.06.002

9. Huang, X., An, D., Song, J., Gao, W., Shen, Y. (2017). Persulfate/electrochemical/ $/ \mathrm{FeCl}_{2}$ system for the degradation of phenol adsorbed on granular activated carbon and adsorbent regeneration. Journal of Cleaner Production, 165, 637-644. https://doi.org/10.1016/j.jclepro.2017.07.171

10. Wei, H., Deng, S., Huang, Q., Nie, Y., Wang, B., Huang, J., Yu, G. (2013). Regenerable granular carbon nanotubes/alumina hybrid adsorbents for diclofenac sodium and carbamazepine removal from aqueous solution. Water Research, 47 , 4139-4147. https://doi.org/10.1016/j.watres.2012.11.062

11. Shu, Z., Chen, Y., Zhou, J., Li, T., Sheng, Z., Tao, C., Wang, Y. (2016). Preparation of halloysite-derived mesoporous silica nanotube with enlarged specific surface area for enhanced dye adsorption. Applied Clay Science, 132-133, 114-121. https://doi.org/10.1016/j.clay.2016.05.024

12. Siddiqui, S. I., Fatima, B., Tara, N., Rathi, G., Chaudhry, S. A. (2019). Recent Advances in remediation of synthetic dyes from wastewaters using sustainable and low-cos adsorbents. In The Impact of and Prospects of Green Chemistry for 
Textile Technology; The textile Institute Book Series; (Ed. S. ul-Islam). Elsevier Science: Amsterdam, The Netherlands. 471-507. DOI: 10.1016/B978-0-08-102491-1.00015-0

13. Vogel, A. A., Somin, V. A., Komarova, L. F. (2011). The study of the sorption properties of materials based on waste wood and mineral raw materials. Chemistry for sustainable development, 19, 461-465 [in Russian].

14. Chesnokov, N. V., Mikova, N. M., Ivanov, I. P., Kuznetsov, B. N. (2014). Obtaining carbon sorbents by chemical modification of fossil coals and plant biomass. Journal of Siberian Federal Universiti. Chemistri, 1(7), 42-53 [in Russian].

15. Domracheva, V. A., Gandandorj, Shiirav. (2012). Carbon sorbents from mongolian brown coals. Proceedings of the Mongolian Academy of Sciences, 52(04), 20-28

16. Nikitina, N. V., Komov, D. N., Kazarinov, I. A., Nikitina N. V. (2016). Physical and chemical properties of sorbents based on bentonite clay, modified with iron (III) and aluminum polyhydroxocations by the «coprecipitation». Sorption and chromatographic processes, 16(2), 191-199 [in Russian].

17. Domracheva, V. A., Vescheva, E. N. (2010). Modification of carbon orbents to improve the efficiency of heavy metals extraction from sewage and technogeneous entities. Bulletin of Irkutsk State Technical University, 4, 134-138

18. Mo, W., He, Q., Su, X., Ma, S., Feng, J., He, Z. (2018). Preparation and characterization of a granular bentonite composite adsorbent and its application for $\mathrm{Pb}^{2+}$ adsorption. Applied Clay Science., 159, 68-73. https://doi.org/10.1016/j. clay.2017.12.001

19. Mangwandi, C., Suhaimi, S. N. A., Liu, J. T., Dhenge, R. M., Albadarin, A. B. (2016). Design, production and characterisation of granular adsorbent material for arsenic removal from contaminated wastewater. Chemical Engineering Research and Design, 110, 70-81. https://doi.org/10.1016/j.cherd.2016.04.004

20. Tagaev, I. A., Tursunova, S. U., Andriyko, L. S. (2018). Investigation and selection of initial materials as possible sources for obtaining sorbents. Chemistry, Physics and Technology of Surface, 9(4), 432-441 DOI: 10.15407/hftp09.04.432

21. Patent RF №2023661, Method of producing activated coal and system of equipment for productionof said activated coal. S.N. Kulishov [in Russian].

22. Patent RU 2051094, Method for producing activated carbon and plant for its implementation. Dvoskin G.I., Starostin A.D., Molchanova I.V. [in Russian].

23. GOST R 54246-2010. Coal - determination of bulk density. Moscow: 2012, 12 p. [in Russian].

24. GOST 17219-71. Active carbons. Method for determination of summary pore volume by the moisture capacity test. Moscow: 2007. 5 p. [in Russian].

25. Mukhin, V. M. (2016). Activated carbons as an important factor in the development of the economy and solving environmental problems. Chemistry in the interests of sustainable development, 24(3), 309-316 [in Russian]. DOI: 10.15372/ KhUR20160305

26. Smirnova, A .D. (1982). Sorption purification of water. Leningrad: Chemistry.168 p. [in Russian].

27. Greg, S. (1984). Adsorption, specific surface area, porosity. - Moscow [in Russian].

28. Tarasevich, Yu. I. (1981). Natural sorbents in water purification processes. Kiyv [in Russian].

29. Keltsev, N. V. (1984). Fundamentals of adsorption technology. Moscow [in Russian].

30. Experimental methods in adsorption and molecular chromatography. (1990). (Ed. Yu. S. Nikitina and R. S. Petrova). Moscow [in Russian].

31. Brunauer S. Adsorption of gases and vapors; trans. from English under the editorship of Acad. M. M. Dubinina, Moscow, 1948. 781p. [in Russian].

32. Rouquerol, F., Rouquerol, J., Sing, K. (1998). Adsorbtion by powders and porous solids. principles, methodology and application. Academic Press. 467 p.

33. Barrett, E. P., Joyner, L. G., Halenda, P. P. (1951). The determination of pore volume and area distributions in porous substances. I. Computations from nitrogen isotherms. Journal of the American Chemical Society, 73, 373-380. https:// doi.org/10.1021/ja01145a126

34. Turov, V. V., Gunko, V. M., Leboda, R., Bandosz, T. J., Skubiszewska-Zi ba, J., Palijczuk, D., Zietek S. (2002). Influence of Organics on the Structure of Water Adsorbed on Activated Carbons. Journal of Colloid and Interface Science, 253(1), 23-34 https://doi.org/10.1006/jcis.2002.8547

35. Grajek, H. (2000). Regeneration of adsorbents by use of liquid subcritical and supercritical carbondioxide. Adsorption Science \& Technology, 18(4), 347-371. https://doi.org/10.1260/0263617001493486

Received 03.08.2020

Revised 01.12.2020

Accepted 23.02.2021 
I.A. Tazaєe ${ }^{1}$ (https://orcid.org/0000-0002-4268-7336),

М.Н. Муратова ${ }^{1}$ (https://orcid.org//0000-0001-6204-9182),

Л.С. Андрійко (https://orcid.org/0000-0001-5558-5374),

М.Ю. Бойхонова ${ }^{1}$ (https://orcid.org//0000-0001-8487-9443)

${ }^{1}$ Навоїйський державний гірничий інститут, просп. Галаба, 170, Навої, 210100, Узбекистан,

+998 0436223 4966, info@ndki.uz

${ }_{2}^{2}$ Інститут хімії поверхні ім. О.О. Чуйка Національної академії наук України, вул. Генерала Наумова, 17, Київ, 03164, Україна,

+380 444243567 , info@isc.gov.ua

${ }^{3}$ Навоїйська філія АН Узбекистану, просп. Галаба, 170, Навої, 210100, Узбекистан, +998 79223 4215, navoiy@academy.uz

\section{ХАРАКТЕРИСТИКИ НОВИХ ПЕРСПЕКТИВНИХ БЕНТОНІТО-ВУГІЛЬНИХ СОРБЕНТІВ, МОДИФІКОВАНИХ РІЗНИМИ СПОЛУКАМИ}

Вступ. Бентонітові глини - це традиційні недорогі та ефективні адсорбенти, що мають високий потенціал для вилучення важких металів зі стічних вод через їх доступність, хімічну та механічну стійкість, високу здатність до обміну та унікальні структурні властивості.

Проблематика. Для отримання активованого вугілля використовуються високотемпературні муфельні печі, які споживають значний обсяг електроенергії, що є економічно невигідним. Крім того, отримані сорбенти повинні бути у вигляді гранул або таблеток, мати високу міцність і можливість багаторазово використовуватися в технологічних процесах.

Мета. Розробка способу виробництва низьковартісних гранульованих сорбентів на основі бентоніту як мінерального компонента, активованого вугілля, а також природніх відходів виробництва як модифікаторів, що можуть бути вилучені з процесу активації, з метою підвищення пористості матеріалів.

Матеріали та методи. Ангренське буре вугілля; бентоніт Навбахорського родовища використовувався як сорбент і базова речовина для формування гранул; модифікаторами слугували хлориди натрію, калію, подрібнена солома, тирса. Застосовано методи термічної декарбонізації та активації одержаних гранул, встановлено оптимальні умови $\left(950{ }^{\circ} \mathrm{C}, 45 \mathrm{xв}\right)$; визначено насипну щільність, методами оптичної мікроскопії та адсорбції азоту встановлено величину питомої поверхні, види пор та їх сумарний об'єм.

Результат. Синтезовано гібридні бентоніто-вуглецевих сорбенти у вигляді високоміцних гранул. Встановлено оптимальне співвідношення Бентоніт:Вугілля = $1: 2$, розмір (2,5 мм) та міцність гранул (83-99 \%), загальний об'єм пор: 0.863-1.01 см³ $/$ г, підтверджено наявність макро-, мезо- та мікропор. Виділено найбільш перспективний зразок з питомою поверхнею (по Ленгмюру) $184 \mathrm{~m}^{2} /$ г.

Висновки. Запропоновано методику одержання нових ефективних гранульованих вуглецевих сорбентів низької собівартості, що мають високу сорбційну здатність щодо органічних та неорганічних сполук для очищення промислових технологічних вод.

Ключові слова: вугілля, бентонітові глини, активація, карбонізація, мікроскопічна структура, бентоніто-вугільні сорбенти. 